\title{
INVESTIGATION ON MECHANICAL PROPERTIES OF SILICA AND GGBS INCORPORATED CEMENT MORTAR
}

\author{
Maitri Mapa ${ }^{1}$, Hemalatha, ${ }^{2}{ }^{2}$, Rama Chandra Murthy A. ${ }^{3}$ \\ ${ }^{1}$ Quick Hire Scientist, CSIR -Structural Engineering Research Centre, CSIR Complex, Taramani, Chennai-113, \\ ${ }^{2}$ Scientist, CSIR -Structural Engineering Research Centre, CSIR Complex, Taramani, Chennai-113, \\ ${ }^{3}$ Senior Scientist CSIR -Structural Engineering Research Centre, CSIR Complex, Taramani, Chennai-113,
}

\begin{abstract}
Synopsis
The usage of mineral admixture in concrete is mounting with regards to socio-economic understanding, energy conservation, and environmental preservation, as well as for better engineering and performance of concrete. However, more usage of supplementary cementitious material in concrete is restricted due to lack of gain in strength at early ages. In this study, an attempt has been made to investigate the effect of partial replacement of cement with various percentages of GGBS on mechanical properties. Cement was replaced with GGBS in the proportions of 20\%, 40\%, 60\%, 80\% respectively and compressive strength test has been conducted at mortar level from $1^{\text {st }}$ to $90^{\text {th }}$ day under normal water curing. It has been observed that, the compressive strength of mortar is decreasing at all days, generally, and at early ages, particularly with the increasing replacement of GGBS. To compensate the loss in strength, silica rich admixtures, such as densified silica fume, nano silica and micro silica have been blended with the GGBS in cement during mortar mix preparation. The compressive strength of silica blended mortar mixes has shown good enhancement at early ages, compared to the GGBS-cement mix. Among all siliceous compounds, addition of $1 \%$ nano and 5\% mico silica show better improvement at early age compressive strength.
\end{abstract}

Key words: GGBS, nano silica, mechanical properties

\section{INTRODUCTION}

Cement can be considered as one of the most polluting materials, still widely used as construction material. Restriction on wide usage of cement are followed as a part of energy conservation, environmental preservation and socio-economic benefit. A significant amount of international research are going on with different alternative cement binders in recent years to develop optimum mixture. The mineral admixtures with pozzolanic properties such as fly ash (FA), silica fume (SF), ground blast-furnace slag (GGBS) and metakaolin (MK) are commonly used as a partial substitution of Portland cement during construction. These admixtures are often added to modify the physical and chemical properties of cementitious mixes, performances and engineering properties of the concrete, as well [1-3].

GGBS has been used in large quantities as a supplementary cementitious material for many years in concrete as a component of blended cement because of its inherent cementitious properties and chemical composition which are broadly similar to the cement's chemical composition. In comparison to ordinary Portland cement, the collection of GGBS as a by-product requires less energy and it produces less greenhouse gases. Thus, GGBS blended concrete is a more environmentally friendly concrete compared to OPC concrete. Furthermore, GGBS-blended cement paste has better water impermeability characteristics as well as improved corrosion resistance and sulphate attack prevention properties[4-5]. All the effect combined together enhances the service life of a structure followed by overall maintenance cost [6]. High volume replacement of ecofriendly GGBS leads to the development of concrete, which not only utilizes the industrial wastes but also saves significant natural resources and energy and decreases the land filling problems due to the accumulation of waste materials. However, lack of strength gain at early ages restricts the extensive usage of GGBS in concrete. In order to improve this pozzolanic activity and early age mechanical strength, some silica based materials are added with GGBS during casting of cement mortar [7-8].

In this paper, the analysis are done on the potential application of micro and nano sized silica based materials for improvement of the initial strength of blended cements and the effect of those materials on the compressive strength properties of blended cement mortars specially at early ages are discussed. Silica based materials plays a significant role on the formation of more C-S-H gel during the hydration of cement particles, which can fill more number of available pores and improves ultimately the microstructure in hardened state. As the microstructure becomes more compact, the mechanical properties are expected to be improved at early ages [9-11]. In this aspect, densified silica fume also has been explored in this study.

\section{MATERIALS AND METHODS}

Both the binding materials Portland cement and GGBS used in this study are procured in India. Cement used in this study is ordinary Portland cement (53 Grade) conforming to ASTM C150-02. GGBS was procured from M/s Quality Polytech, Karnataka, India. Locally available river sand 
passing through IS sieve $2.69 \mathrm{~mm}$ was used as fine aggregate. Mortar composition was based on EN 196-1, consisted of one part cement to three parts river sand. Potable water is used for casting and curing. Nano Silica and micro silica was procured from Sigma-Aldrich Company. The chemical composition and physical properties of the materials used for this study are presented in Table1 and 2. The percentages of replacement of GGBS in cementitious materials were $20,40,60$ and 80 by weight of cement.

Table 1. Typical chemical composition Cement, GGBS, Densified Silicafume (SF), Nano Silica (NS) and Micro

\begin{tabular}{|c|c|c|c|c|c|c|c|c|}
\hline \multicolumn{9}{|c|}{ silica (MS) } \\
\hline $\begin{array}{l}\text { Chemica } \\
1 \\
\text { composi } \\
\text { tion } \%\end{array}$ & $\begin{array}{l}\mathrm{Si} \\
\mathrm{O}_{2}\end{array}$ & $\begin{array}{l}\mathrm{Al}_{2} \\
\mathrm{O}_{3}\end{array}$ & $\begin{array}{l}\mathrm{C} \\
\mathrm{a} \\
\mathrm{O}\end{array}$ & $\begin{array}{l}\mathrm{Fe}_{2} \\
\mathrm{O}_{3}\end{array}$ & $\begin{array}{l}\mathrm{M} \\
\mathrm{gO}\end{array}$ & $\begin{array}{l}\mathrm{Na}_{2} \\
\mathrm{O}+ \\
\mathrm{K}_{2} \\
\mathrm{O}\end{array}$ & $\begin{array}{l}\mathrm{S} \\
\mathrm{O} \\
3\end{array}$ & $\begin{array}{l}\text { Los } \\
s \\
\text { of } \\
\text { ignit } \\
\text { ion }\end{array}$ \\
\hline Cement & $\begin{array}{l}21 \\
.5\end{array}$ & 5.5 & $\begin{array}{l}63 \\
.6\end{array}$ & 4.5 & 20 & 0.6 & $\begin{array}{l}1 . \\
6\end{array}$ & 2.8 \\
\hline GGBS & $\begin{array}{l}35 \\
.5\end{array}$ & $\begin{array}{l}13 . \\
3\end{array}$ & $\begin{array}{c}40 \\
.8\end{array}$ & 1.2 & 8.6 & 0.8 & $\begin{array}{l}0 . \\
2\end{array}$ & 0.2 \\
\hline NS & $\begin{array}{l}99 \\
.5\end{array}$ & 0.1 & $\begin{array}{l}0 . \\
1\end{array}$ & 0.2 & 0.1 & - & - & - \\
\hline MS & $\begin{array}{l}9 \\
2 \\
- \\
98\end{array}$ & $\begin{array}{l}0.4 \\
- \\
0.9\end{array}$ & $\begin{array}{l}0 . \\
2 \\
- \\
0 . \\
7\end{array}$ & $\begin{array}{l}1- \\
2\end{array}$ & 0.3 & - & - & - \\
\hline $\begin{array}{l}\text { Densifie } \\
\mathrm{d} \text { silica } \\
\text { fume }\end{array}$ & $\begin{array}{l}85 \\
.5\end{array}$ & 0.5 & $\begin{array}{l}1 . \\
4\end{array}$ & 1.3 & 4.8 & 2.6 & $\begin{array}{l}1 . \\
3\end{array}$ & 2.5 \\
\hline
\end{tabular}

Table 2. Typical physical properties Cement, GGBS, Densified Silicafume (SF), Nano Silica (NS) and Micro silica (MS)

\begin{tabular}{|l|l|l|l|l|l|}
\hline $\begin{array}{l}\text { Physical } \\
\text { properti } \\
\text { es }\end{array}$ & $\begin{array}{l}\text { Ceme } \\
\mathrm{nt}\end{array}$ & $\begin{array}{l}\text { GGB } \\
\mathrm{S}\end{array}$ & $\begin{array}{l}\text { Densifi } \\
\text { ed } \\
\text { Silica } \\
\text { fume }\end{array}$ & $\begin{array}{l}\text { Nano } \\
\text { Silica }\end{array}$ & $\begin{array}{l}\text { Micr } \\
\text { o } \\
\text { silic } \\
\text { a }\end{array}$ \\
\hline Colour & Grey & $\begin{array}{l}\text { Off- } \\
\text { Whit } \\
\mathrm{e}\end{array}$ & Grey & White & $\begin{array}{l}\text { Whit } \\
\mathrm{e}\end{array}$ \\
\hline $\begin{array}{l}\text { Specific } \\
\text { gravity }\end{array}$ & 3.15 & 2.9 & 2.2 & 2.4 & 2.21 \\
\hline $\begin{array}{l}\text { Bulk } \\
\text { density }\end{array}$ & $\begin{array}{l}320 \\
\mathrm{~kg} / \mathrm{m}^{3}\end{array}$ & $\begin{array}{l}1200 \\
\mathrm{~kg} / \mathrm{m} \\
3\end{array}$ & $\begin{array}{l}650 \\
\mathrm{~kg} / \mathrm{m}^{3}\end{array}$ & $\begin{array}{l}2200 \mathrm{~kg} / \\
\mathrm{m}^{3}\end{array}$ & $\begin{array}{l}540 \\
\mathrm{~kg} / \mathrm{m} \\
3\end{array}$ \\
\hline $\begin{array}{l}\text { Finenes } \\
\mathrm{s}\end{array}$ & $\begin{array}{l}364 \\
\mathrm{~m}^{2} / \mathrm{kg}\end{array}$ & $\begin{array}{l}554 \\
\mathrm{~m}^{2} / \mathrm{k} \\
\mathrm{g}\end{array}$ & $\begin{array}{l}13.9 \\
\mathrm{~kg} / \mathrm{m}^{3}\end{array}$ & $640 \mathrm{~m}^{2} / \mathrm{g}$ & \\
\hline
\end{tabular}

\subsection{Specimen Preparation And Curing}

To understand the quantity of water required for casting, standard consistency test and setting time experiments have been performed. From the obtained results, the optimum water to binder ratio was determined, and based on that casting of mortars have been carried out. Preparation of the mix has been carried out in Hobart mixer at room temperature in steps as given below.

- Material is dry mixed for first 150 seconds at very slow speed.

- Then $80 \%$ of the total required water is added initially and it was mixed for 120 seconds at a minimum speed.

- After mixing for 120 seconds, mixer is stopped and sides of basin is scrapped and again mixed for 30 seconds. The mixing is stopped and remaining water is added. No super plasticiser was introduced to the mixes.

- The mix is then thoroughly blended for another 30 seconds and mixing is stopped and mix is kept undisturbed for 2 minutes.

- Finally, the mortar is mixed for 120 seconds at higher speed before poured in the respective mould. From each different mortar mixture, fifteen $50 \mathrm{~mm}$ cubes were cast for the determination of the compressive strength.

- Casting of cubes were vibrated in three layers. Each layer was compacted by internal vibration and top surface was leveled and smoothened using a trowel. The test specimens were cured according to ASTM C192-88 in potable water at room temperature.

To add silica enrich material, first required amount of nano/micro silica or densified silica fume, has been sonicated with water for 15 minutes. Immediately after sonication dispersed nano material in water was added to the casting mix during preparation in Hobart mixer.

After 24-hour of casting, the specimens were demolded and cured in potable water until testing. After the required time of curing, the specimens are taken out from curing tank and dried at room temperature and tested for compressive strength, split tensile and flexural strength. Mix proportion and their coding have been listed in Table 3.

Table 3 Mix proportioning of mortars

\begin{tabular}{|c|c|c|c|c|c|c|}
\hline Mix Ratio & $\begin{array}{l}\text { CEME } \\
\text { NT } \\
(\mathbf{k g})\end{array}$ & $\begin{array}{l}\text { SAN } \\
\text { D } \\
(\mathbf{k g})\end{array}$ & $\begin{array}{l}\text { GG } \\
\text { BS } \\
(\mathbf{k g})\end{array}$ & $\begin{array}{l}\text { DS } \\
\text { F } \\
(\mathbf{k g})\end{array}$ & $\begin{array}{l}\text { NS } \\
(\mathbf{k g})\end{array}$ & $\begin{array}{l}\text { W/ } \\
\text { b } \\
\text { rati } \\
\text { o }\end{array}$ \\
\hline CEM & 2.6 & 7.8 & 0 & 0 & 0 & $\begin{array}{l}0.4 \\
25\end{array}$ \\
\hline CEM20GS & 2.08 & 7.8 & $\begin{array}{l}0.51 \\
2\end{array}$ & 0 & 0 & $\begin{array}{l}0.4 \\
4\end{array}$ \\
\hline CEM40GS & 1.56 & 7.8 & 1.04 & 0 & 0 & $\begin{array}{l}0.4 \\
5\end{array}$ \\
\hline CEM60GS & 1.04 & 7.8 & 1.56 & 0 & 0 & $\begin{array}{l}0.4 \\
65\end{array}$ \\
\hline CEM80GS & 0.520 & 7.8 & 2.08 & 0 & 0 & $\begin{array}{l}0.4 \\
8\end{array}$ \\
\hline $\begin{array}{l}\text { CEM35GS5 } \\
\text { SF }\end{array}$ & 1.56 & 7.8 & $\begin{array}{l}0.91 \\
0 \\
\end{array}$ & $\begin{array}{l}0.1 \\
30 \\
\end{array}$ & 0 & $\begin{array}{l}0.4 \\
5\end{array}$ \\
\hline $\begin{array}{l}\text { CEM55GS5 } \\
\text { SF }\end{array}$ & 1.04 & 7.8 & 1.43 & $\begin{array}{l}0.1 \\
30 \\
\end{array}$ & 0 & $\begin{array}{l}0.4 \\
65\end{array}$ \\
\hline $\begin{array}{l}\text { CEM40GS5 } \\
\text { MS }\end{array}$ & 1.56 & 7.8 & 1.04 & 0 & $\begin{array}{l}0.2 \\
6\end{array}$ & $\begin{array}{l}0.4 \\
5\end{array}$ \\
\hline $\begin{array}{l}\text { CEM60GS5 } \\
\text { MS }\end{array}$ & 1.04 & 7.8 & 1.56 & 0 & $\begin{array}{l}0.2 \\
6 \\
\end{array}$ & $\begin{array}{l}0.4 \\
65 \\
\end{array}$ \\
\hline
\end{tabular}




\begin{tabular}{|l|l|l|l|l|l|l|}
\hline $\begin{array}{l}\text { CEM40GS1 } \\
\text { NS }\end{array}$ & 1.56 & 7.8 & 1.04 & 0 & $\begin{array}{l}0.0 \\
52\end{array}$ & $\begin{array}{l}0.4 \\
5\end{array}$ \\
\hline $\begin{array}{l}\text { CEM60GS1 } \\
\text { NS }\end{array}$ & 1.04 & 7.8 & 1.56 & 0 & $\begin{array}{l}0.0 \\
52\end{array}$ & $\begin{array}{l}0.4 \\
65\end{array}$ \\
\hline
\end{tabular}

\section{EXPERIMENTAL PROCEDURE}

\subsection{Consistency}

The basic aim of consistency test is to find out the water content required to produce a cement paste of standard consistency as specified by ASTM C191.The consistency, initial and final setting time of pure cement paste and cement paste replaced by GGBS is determined and results are shown in Table 4.

Table 4. Consistency results of GGBS incorporated cement

\begin{tabular}{|c|c|c|c|c|c|c|}
\hline \multicolumn{7}{|c|}{ paste } \\
\hline $\begin{array}{l}\text { S } \\
\mathbf{L} \\
\mathbf{N} \\
\mathbf{0}\end{array}$ & $\begin{array}{l}\text { Sampl } \\
\text { e }\end{array}$ & $\begin{array}{l}\text { Ceme } \\
\text { nt } \\
(\mathrm{g})\end{array}$ & $\begin{array}{l}\text { GG } \\
\text { BS } \\
(\mathrm{g})\end{array}$ & $\begin{array}{l}\text { Consiste } \\
\text { ncy }(\%)\end{array}$ & $\begin{array}{l}\text { Initi } \\
\text { al } \\
\text { Setti } \\
\text { ng } \\
\text { Time } \\
\text { (hrs) }\end{array}$ & $\begin{array}{l}\text { Final } \\
\text { Setti } \\
\text { ng } \\
\text { Time } \\
\text { (hrs) }\end{array}$ \\
\hline 1 & CEM & 400 & 0 & 30.5 & 2 & 4.15 \\
\hline 2 & $\begin{array}{l}\text { CE20 } \\
\text { GS }\end{array}$ & 320 & 80 & 32 & 2.35 & 4.40 \\
\hline 3 & $\begin{array}{l}\text { CE40 } \\
\text { GS }\end{array}$ & 240 & 160 & 33 & 3.10 & 4.45 \\
\hline 4 & $\begin{array}{l}\text { CE60 } \\
\text { GS }\end{array}$ & 160 & 240 & 34.5 & 3.30 & 4.50 \\
\hline 5. & $\begin{array}{l}\text { CE80 } \\
\text { GS }\end{array}$ & 80 & 320 & 35.5 & 4.30 & 6.00 \\
\hline
\end{tabular}

The consistency and setting times (the initial and the final) of the cement pate increased with the increased percentage of GGBS contents in the mix. According to Table 4, the water demand is more for the cement paste with high volume of GGBS (HVGGBS) than the control. The initial setting time increases in the range of $29 \%, 58 \%$, and $75 \%$ for CE-20-40-60GS cement paste specimens respectively, in comparison to pure ordinary Portland cement (OPC) paste. The increase of final setting time is in the range of $10 \%, 12 \%$, and $14 \%$, for CE-20-40-60GS cement paste specimens respectively with respect to pure OPC paste. Increase in the initial setting time indicates that the addition of GGBS retards the initial hydration of the cements. However, final setting time is not affected in a similar way as that of initial setting time by the replacement of cement by GGBS. According to the standard setting time results, the minimum initial setting time value obtained for all cement paste specimens are above $60 \mathrm{~min}$, and the maximum final setting time value obtained for all cement paste specimens are below 600 min, which are defined by TS EN 196-3. With SF/MS/NS addition, the initial setting times of cement -GGBS mix has been decreased, however that is within the limit defined by TS EN 196-3.

\subsection{Experimental Results for Cement Mortar} Modified With GGBS

\subsubsection{Compressive Strength of Cement-GGBS}

\section{Mortar}

Compressive strength test are performed to investigate the strength of GGBS incorporated cement mortar at 1, 3, 7, 28 and 90 days under normal water curing. The average of three samples was taken for every testing age [12-14]. The compressive strength test results are displayed in Fig 1. The compressive strength of cement mortar decreases severely at early ages with the increased replacement levels of GGBS in cement. In comparison with control cement cubes, the strength decreases by $9.58 \%$ at $1^{\text {st }}$ day, $15.87 \%$ at $3^{\text {rd }}$ day, $20.75 \%$ at $7^{\text {th }}$ day, $9.11 \%$ at $28^{\text {th }}$ day and only $4.08 \%$ at $90^{\text {th }}$ day for CEM20GS. Mortar cubes of CEM40GS shows that the strength decreases by $14.25 \%$ at $1^{\text {st }}$ day, $31.16 \%$ at $3^{\text {rd }}$ day, $30.45 \%$ at $7^{\text {th }}$ day, $12.75 \%$ at $28^{\text {th }}$ day and $6.62 \%$ at $90^{\text {th }}$ day with respect to control cement mortar cubes. In case of CEM60GS mortar cubes, the strength decreases by $61.70 \%$, $64.96 \%, 64.03 \%, 43.59 \%$ and $28.11 \%$ at $1^{\text {st }}, 3^{\text {rd }}, 7^{\text {th }}, 28^{\text {th }}$ and $90^{\text {th }}$ day respectively of curing in comparison to control cement mortar cubes. For CEM80GS, the strength decreases by more than approximately $70 \%$ at $1^{\text {st }}, 3^{\text {rd }}, 7^{\text {th }}$ and $28^{\text {th }}$ day of curing and $60.62 \%$ at $90^{\text {th }}$ day of curing with respect to control cement mortar. It is noticed that with increase in the curing days, the effect on strength reduction due to GGBS incorporation is decreasing. This may be due to the initial slow pozzolanic reaction for the GGBS replacement which mainly depends on the availability of calcium hydroxide and silica. This reaction rate might have accelerated at the later ages and thus the strength gain process takes longer time for the GGBS added mortars. However, effect of replacement of GGBS in compressive strength test is not so distinct in CEM20GS mortar specimens for all days and also for CEM40GS mortar specimens at 28 and 90-day of curing. The negative effect of GGBS replacement on mechanical strength has been observed very noticeably for $60 \%$ and 80 $\%$ replacement, for all days.

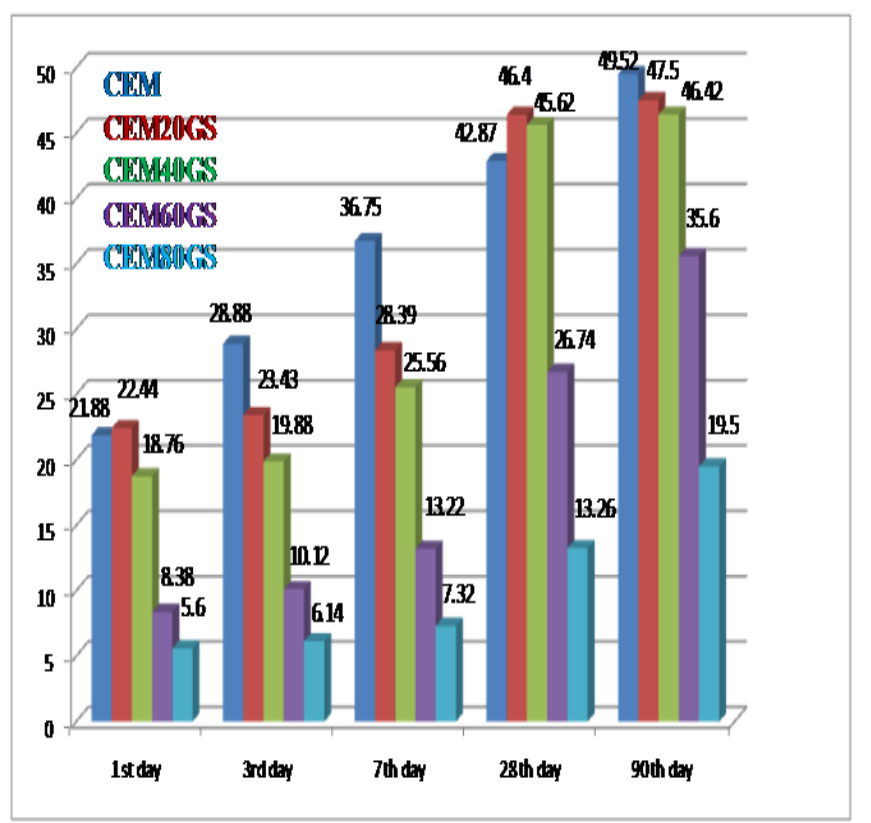

Fig 1. Compressive strength values of GGBS incorporating cement mortar 


\subsubsection{Compressive Strength Of GGBS-Cement}

\section{Mortar Modified With Silica Rich Materials}

\section{Addition}

To improve the pozzolanic reaction in the GGBS incorporated cement mortar and to recover the loss in early age strength, some silica based chemical admixtures are added with GGBS in cement mortar. It is expected that, silica may increase early hydration reaction rate of GGBScement by producing more $\mathrm{C}-\mathrm{S}-\mathrm{H}$. The comparison of average compressive strength of various silica substituted CEM40GS are summarized in Fig. 2. Similar way, the comparison of compressive strength of various silica incorporated CEM60GS are summarized in Fig. 3.

It is observed that, CEM40GS specimen shows lesser compressive strength than that of control mortar. The compressive strength of cement mortar decreases slightly with incorporation of silica fume, and increases efficiently with the incorporation of micro silica and nano silica, separately. The CEM40GS mortar cubes with micro silica replacement exhibited comparable compressive strength values both at early ages (within 7 days) and later ages (upto 90th day ) with that of control mortar (OPC). However, it shows about 70 to $99 \%$ higher compressive strengths at early days with respect to CEM40GS specimens. The less improvement in compressive strength of mortars cubes containing densified silica fume can be attributed to the poor dispersion due to agglomeration of silica fume in wet mix as its van der Waal's forces are higher than that of cement. Although, it is reaching more compressive strength values at early ages with respect to CEM40GS.

It can be seen from Fig. 2 that at $1^{\text {st }}, 3^{\text {rd }}$ and $7^{\text {th }}$ day compressive strength of mortar containing $40 \%$ GGBS is increased by about $73 \%, 97 \%$, and $63 \%$ respectively due to addition of $1 \%$ nano-silica and yet, at $28^{\text {th }}$ and $90^{\text {th }}$ day, further improvement in strength is not noticed, indicating the effectiveness of nano-silica in compensating the lower compressive strength at early ages of high volume cement replaced system.

The compressive strength of cement mortar increases with addition silica fume, micro silica and nano silica compared to that of CEM60GS mortar specimen, though the improvement varies with the properties of silica additives. Significant enhancement in early days compressive strengths of mortar containing 55\% of GGBS and $5 \%$ micro silica was noticed with respect to control cement mortar. The results also show drastic improvement at early ages compressive strength compared to CEM60GS specimens which has been pictorially represented in Fig3. It can also be seen in Fig. 3, that $1 \%$ nano-silica incorporation significantly improved the early ages compressive strength of mortar containing 59\% GGBS compared to control specimen, where about $200 \%$ and $170 \%$ improvements are observed, at early ages with respect to CEM60GS mortar specimen, respectively.
At 28 and 90 days of curing the improvements are also noticed $(69 \%$ and $50 \%$ respectively) for the mortar containing $59 \%$ GGBS with $1 \%$ nano- $\mathrm{SiO}_{2}$ with respect to CEM60GS, although the less improvement is observed compared to control OPC mortar specimens. The improvement of compressive strength of HVGGBS concrete containing $59 \%$ GGBS due to addition of $1 \%$ nano- $\mathrm{SiO}_{2}$ is better than that of the mortar containing 39\% GGBS and $1 \%$ nano- $\mathrm{SiO}_{2}$. The effect of densified silica fume substitution has not given the better results when compared to the control mortar mix. However, the micro silica and nano silica incorporation has given the comparable results with that of the control cement mortar. Specially, at $90^{\text {th }}$ day average compressive strength results shows better result than that of control cement mortar.

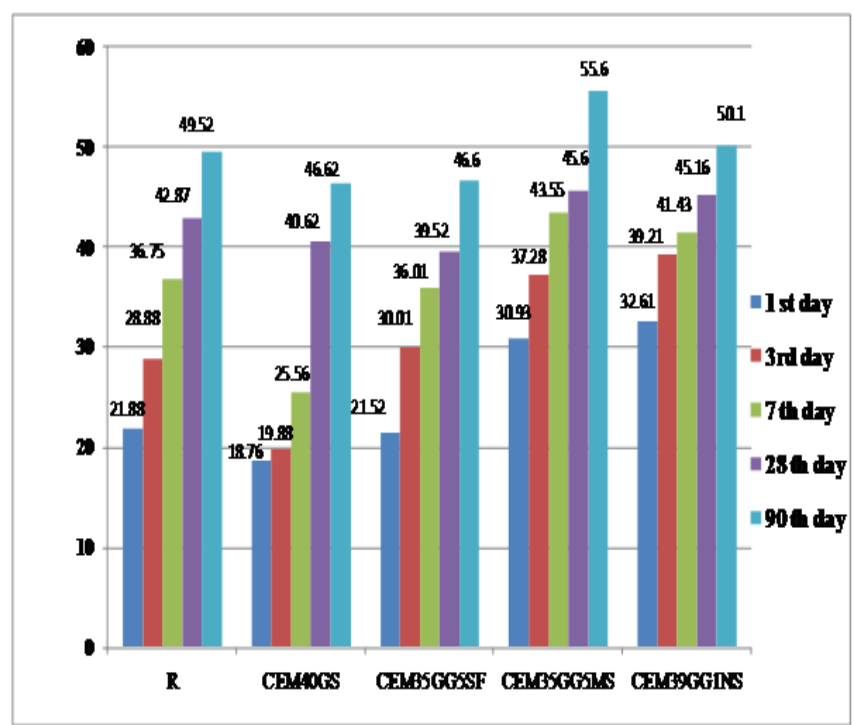

Fig 2. Compressive strength values of $40 \%$ replacement in cement mortar

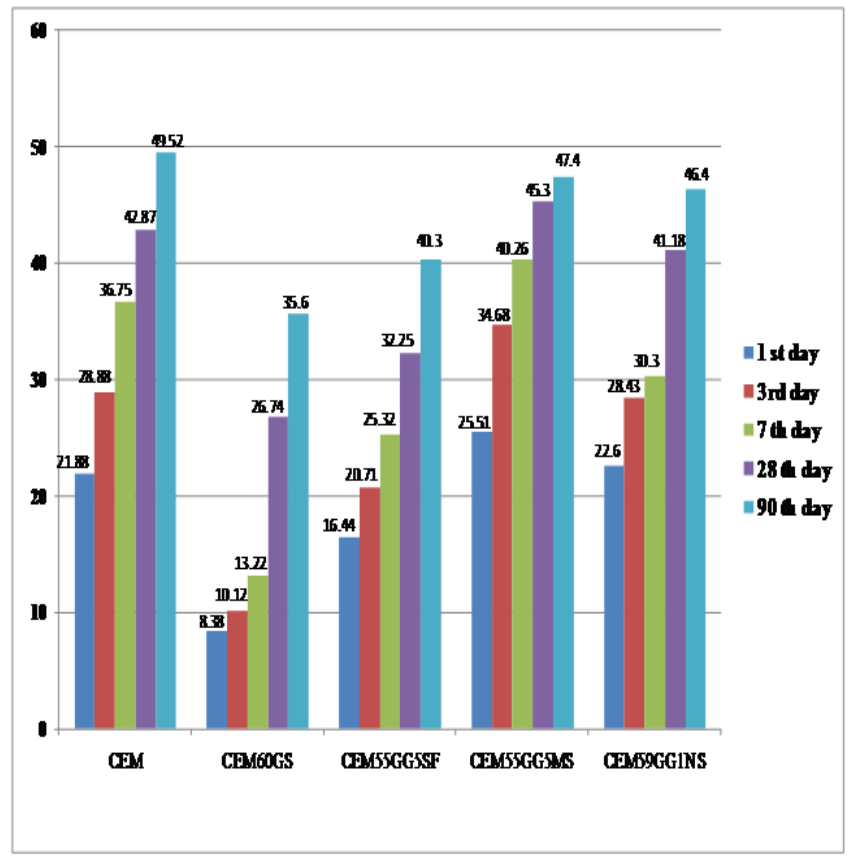

Fig 3. Compressive strength values of $60 \%$ replacement in cement mortar 


\section{CONCLUSIONS}

The following conclusions can be drawn from the experimental results obtained in this study

- The consistency and setting time (the initial and the final) of the cement increased with the increase of GGBS contents. Water demands of blended cements are higher than that of pure cement paste. The increase in initial setting time of GGBS incorporated cement paste is higher than the increase of final setting time with respect to cement paste. It indicates that the addition of GGBS retards the initial hydration of cements.

- $\quad$ The compressive strength of mortar is decreasing at all ages with the increasing replacement of GGBS in cement mortar. However, the effect of replacement of GGBS in compressive strength test is not so distinct in CEM20GS and CEM40GS specimen at 28 and 90 days.

- $\quad$ The compressive strength of silica added mortar mixes has shown good improvement in early ages compressive strength as compared with the GGBScement mix. The early age compressive strength of silica added CEM40GS and CEM60GS is comparable, even better than control mortar.

\section{ACKNOWKEDGEMENT}

This paper is being published with the kind permission of Director CSIR-SERC. Some of instrument from innovation complex has been used.

\section{REFERENCES}

[1]. Elahi A., BasheerP.A.M., Nanu KuttanS.V., and KhanQ.U.Z. 'Mechanical and Durability Properties of High Performance Concrete Containing Supplementry Cementitious Materials', Constr Build Mater, 24 (2010) 292-299.

[2]. Gengying Li, Xiaohua Zhao (2003) 'Properties of Concrete Incorporating Fly Ash and Ground Granulated Blast Furnace Slag' Cement Concrete Comp 25, 2003, pp. 293-299.

[3]. Mohamed Heikal, S. Abd El Aleem, W.M. Morsi (2013) 'Characteristics of blended cements containing nano-silica', HBRC Journal (2013) 9, 243-255.

[4]. Oner A., and Akyuz S. (2007) 'An Experimental Study on Optimum Usage of GGBS for the Compressive Strength of Concrete', Cement Concrete Compos 29, 2007, pp. 505-514.

[5]. Sadok A.H., Kenai S., Courard L. and Anne Darimont A., (2011) 'Microstructure and durability of Mortars Modified with Medium Active Blast Furnace Slag', Constr Build Mater, 25 (2011) pp. 1018-1025.

[6]. Guneyisi. E, and Gesoglu. M 'A study on durability properties of high-performance concretes incorporating high replacement levels of slag', Mater Structur, 2008 40(3) PP. 479-93.

[7]. Khan M., and Usman Ghani 'Effect of Blending of
Portland cement with Ground Granulated Blast Furnace Slag on the Properties of Concrete', $29^{\text {th }}$ Conference on Our World in Concrete and Structures: 25-26 August 2004, Singapore.

[8]. Senff L., LabrinchaJ.A, FerreiraV.M., HotzaD., RepetteW.L. 'Effect of nano-silica on rheology and fresh properties of cement pastes and mortars', Constrbuild mater 23 (2009) pp. 2487-2491.

[9]. Mohamed Heikal, S. Abd El Aleem, W.M. Morsi (2013) 'Characteristics of blended cements containing nano-silica', HBRC Journal (2013) 9, pp. 243-255.

[10]. Qing Y., Zenan., Deyu K., andRongshen C., 'Influence of Nano- $\mathrm{SiO}_{2}$ addition on properties of hardened cement paste as compared with silica fume', Constr build mater , 2007, 21, pp.539-545.

[11]. Arivalagan S. (2014) 'Sustainable Studies on Concrete with GGBS As a Replacement Material in cement', Jordan Journal of Civil Engineering, Vol 8, No. 3, 2014.

[12]. Shariq, M., Prasad, J., and Ahuja, A.K., "Strength Development of Cement Mortar and Concrete Incorporating GGBFS", Asian Journal of Civil Engineering, 2008, 9 (1), 61-74 .

[13]. Shi H. S., Xu B.W. and Zhou X. C. 'Influence of mineral admixtures on compressive strength, gas permeability and carbonation of high performance concrete' Constr Build Mater 2009 23(5) 1980-5.

[14]. Teng S., Darren Lim T. Z., and Divsholi B.S., 'Durability and Mechanical Properties of High Strength Concrete Incorporating ultra fine Ground Granulated Blast-furnace slag', ConstrBuilding Mater 40 (2013) 875-881. 